Les Cahiers d'Afrique de l'Est / The East

African Review

$51 \mid 2016$

Global History, East Africa and The Classical

Traditions

\title{
Ethiopia and India: Fusion and Confusion in British Orientalism
}

Phiroze Vasunia

\section{(2) OpenEdition \\ Journals}

Electronic version

URL: https://journals.openedition.org/eastafrica/314

DOI: 10.4000/eastafrica.314

ISSN: 2790-1076

\section{Publisher}

IFRA - Institut Français de Recherche en Afrique

\section{Printed version}

Date of publication: 1 March 2016

Number of pages: 21-43

ISSN: 2071-7245

\section{Electronic reference}

Phiroze Vasunia, "Ethiopia and India: Fusion and Confusion in British Orientalism", Les Cahiers d'Afrique de l'Est / The East African Review [Online], 51 | 2016, Online since 07 May 2019, connection on 09 December 2021. URL: http://journals.openedition.org/eastafrica/314 ; DOI: https://doi.org/10.4000/ eastafrica.314 


\title{
Ethiopia and India: Fusion and Confusion in British Orientalism
}

Phiroze Vasunia

\author{
Can the Ethiopian change his skinne? or the leopard his spots? \\ Jeremiah 13.23, in the King James Version (1611)
}

May a man of Inde chaunge his skinne, and the cat of the mountayne her spottes? Jeremiah 13.23, in the Bishops' Bible (1568)

I once encountered in Sicily an interesting parallel to the ancient confusion between Indians and Ethiopians, between east and south. A colleague and I had spent some pleasant moments with the local custodian of an archaeological site. Finally the Sicilian's curiosity prompted him to inquire of me "Are you Chinese?"

Frank M. Snowden, Blacks in Antiquity (1970)

The ancient confusion between Ethiopia and India persists into the late European Enlightenment. Instances of the confusion can be found in the writings of distinguished Orientalists such as William Jones and also of a number of other Europeans now less well known and less highly regarded. The durability of the confusion is remarkable and has met with various explanations, political, cultural, and epistemological. "It is a persistence belonging first and foremost though to literary history, for during much of the time of mythologizing there was scarcely any direct or unmediated contact between Europe and either place, and knowledge was text-based"1. That is true and untrue. The persistence is indeed heavily textual: but sea-trade between north-east Africa and India begins in the Hellenistic period and would have been impossible on a literalist reading of the confusion. What is striking about the association in a figure such as Jones, however, is that he wrote in the late eighteenth century, by which time European knowledge of Ethiopia and its location had increased dramatically since antiquity, and that he lived in India, which had its own long history of contact with Ethiopia. Literary history is important, but it cannot by itself explain the tenacious hold that the confusion had over poets, travellers, historians, and scholars into the eighteenth century and indeed beyond. We shall need to look to other factors such as the Bible, race, and the power of the Greco-Roman tradition in order to understand why the spell lasts for as long as it does and why it comes to be broken.

In the late eighteenth century, biblical ethnology and ideas about the Orient and race come together to reaffirm a conflation that goes back some two millennia. These ideas and ethnologies will not survive the nineteenth century but still exert an influence for the early Orientalists. The Bible offers a genealogy in which all human nations can be traced back to Adam, or perhaps to Noah, as Genesis shows most powerfully; it accounts for how peoples who inhabit regions so disparate as East Africa and South Asia can be reckoned as part of the same community of nations. Christianity matters to the discussion about Ethiopia and India in another way since the alleged trajectories of the apostle known as Doubting Thomas and, much later, of the legendary Prester John (Presbyter Johannes) play their part in the shaping of the confusion. But Thomas and Prester John are epiphenomenal to the confusion and not the cause of it. and the confusion long antedates them.

\footnotetext{
${ }^{1}$ Mary Baine Campbell, Asia, Africa, Abyssinia: Writing the Land of Prester John. In Julia Kuehn and Paul Smethurst, (eds.), 21 Travel Writing, Form, and Empire: The Poetics and Politics of Mobility, 21-37 (New York: Routledge, 2009), p.22.
} 
There is also, in this era of the Enlightenment, a fluidity about the categories of race and the Orient that allows for the easy passage between Ethiopia and India, between African and Indian, or between the black and, as one ancient writer would have it, the black but not "intensely" black. The black and the Oriental cannot be cleanly separated from each other and the two categories tend to overlap in several texts. These factors overlay the analyses of intellectuals such as Jones and give the confusion a particularly modern inflexion in addition to the charge that it draws from antiquity.

The confusion is, as I suggested, not the result solely of mistaken geography or incorrect science, since empirical precision and first-hand observation do not always succeed in clearing it up. For some centuries, accurate knowledge about Ethiopia stands in contrast to claims about the whereabouts of the region, its original inhabitants, and their customs. Lorenz auf der Maur notes that the African Association is founded in 1788, the first slave narrative in English, by Olaudah Equiano, appears in 1789, and James Bruce's long account of his travels appears in $1790^{2}$. Maur's implication is that Europe's relationship to Ethiopia undergoes a major shift in these years, but it is difficult to see evidence for the shift even in Jones' late work. Perhaps these developments were not known to Jones, who died in Calcutta in 1794, though they were probably known to Francis Wilford, another Briton in India to whom we shall return. At another level, the chronological marker is less significant than we might think, for the confusion between Ethiopia and India continues into the nineteenth century, despite major developments in the historical and geographical sciences. Ancient contact and migration between Ethiopia and India preoccupy some writers even into the twentieth century ${ }^{3}$. The confusion satisfied longstanding theories about India and Ethiopia, the dark-complexioned foreigner, and the promise of the exotic; it was seen to pose little or no threat to the authority of the Bible. For these and other reasons, it was lodged deep in the heart of epistemological frameworks in the Enlightenment and its appeal has never entirely gone away.

\section{The Orientalists: William Jones}

Let us begin our discussion with the traces of this confusion in the Third Anniversary Discourse, "on the Hindus", which was delivered in Calcutta, on 2nd February 1786, by William Jones. Jones was a British judge at a time when the region of Bengal was under the rule of the East India Company: he said that one of his main areas of attention was India, "not because I find reason to believe it the true centre of population or of knowledge, but, because it is the country, which we now inhabit, and from which we may best survey the regions around us"4. The discourse is most often celebrated for its presentation of what would come to be known as the theory of Indo-European languages, but other parts of the discourse, less familiar than the passage about Indo-European, are nonetheless revealing about Jones' method and interests; they show him engaging with contemporaries such as

${ }^{2}$ Lorenz Auf der Maur, Ethiopia and Abyssinia in English Writing up to 1790. In Proceedings of the XVth International Conference of Ethiopian Studies, Hamburg July 20-25, 2003, ed. by Siegbert Uhlig, 523-31 (Wiesbaden: Harrasowitz, 2006), p.523.

${ }^{3}$ Yaacov Shavit, History in Black: African-Americans in Search of an Ancient Past (New York: Routledge, 2013), pp. 217-229.

${ }^{4}$ William Jones, The Works of William Jones, 13 vols (London: Printed for John Stockdale and John Walker, 1807) 3. p.28. 
Jacob Bryant, the author of $A$ new system, or, An analysis of ancient mythology (1774-76), and with early modern frameworks for historical and religious study.

Jones observes that, since India's old history is clouded by fable, he is compelled to turn to four "media" to satisfy his desire to learn more about the country. He describes these four media as: languages and letters; philosophy and religion; sculpture and architecture; and lastly, the written records of the sciences and the arts. Of these four, the third group is the most directly relevant to our analysis of Ethiopia and India.

The remains of architecture and sculpture in India, which I mention here as mere monuments of antiquity, not as specimens of ancient art, seem to prove an early connection between this country and Africa: the pyramids of Egypt, the colossal statues described by PAUSANIAS and others, the sphinx, and the HERMES Canis, which last bears a great resemblance to the Varáhávatár, or the incarnation of VISHNU in the form of a Boar, indicate the style and mythology of the same indefatigable workmen, who formed the vast excavations of Cánárah, the various temples and images of BUDDHA, and the idols, which are continually dug up at Gayá, or in its vicinity. The letters on many of those monuments appear, as I have before intimated, partly of Indian, and partly of Abyssinian or Ethiopick, origin; and all these indubitable facts may induce no ill-grounded opinion, that Ethiopia and Hindustàn were peopled or colonized by the same extraordinary race; in confirmation of which, it may be added, that the mountaineers of Bengal and Bahár can hardly be distinguished in some of their features, particularly their lips and noses, from the modern Abyssinians, whom the Arabs call the children of CÚSH: and the ancient Hindus, according to STRABO, differed in nothing from the Africans, but in the straitness and smoothness of their hair, while that of the others was crisp or woolly; a difference proceeding chiefly, if not entirely, from the respective humidity or dryness of their atmospheres: hence the people who received the first light of the rising sun, according to the limited knowledge of the ancients, are said by APULEIUS to be the Arü and Ethiopians, by which he clearly meant certain nations of India; where we frequently see figures of BUDDHA with curled hair apparently designed for a representation of it in its natural state. ${ }^{5}$

(Jones 1807: 3.40-42)

In this passage, Jones contradicts the implications of the Indo-European hypothesis that he outlined earlier in the same discourse. Perhaps the contradiction is unsurprising since the implications of the Indo-European theory have yet to be developed with any rigour or in detail. Jones sees numerous associations and connections in this discourse that others, and even he himself, would later revise or reject. Jones also undercuts his theory in other places in this discourse: he appears to include Egypt in the grouping of Indo-European cultures, for example, and ends by hinting at putative similarities between Indians, Chinese, Japanese, and Peruvians, among other peoples. In showing a degree of incoherence, at least from our perspective, about the Indo-European hypothesis, Jones connects India and Africa on architectural, linguistic, and racial lines, and these striking correlations call for some comment.

\footnotetext{
${ }^{5}$ The Oxford English Dictionary, 3rd edn., s.v. "Abyssinian", points out that Abyssinia is "the former European name of the country in north-eastern Africa now called Ethiopia". Further: "The Ethiopian Empire was founded in 1270, when its ruling dynasty was formed from an Ethiopic people now usually referred to as Habesha in English (compare Geez habaśā, Amharic hābešă; > Arabic habaš (collective noun), habaša (singular noun) . . . The Empire ended in 1974, and the place name Abyssinia, which was never official, is now only used historically. Early modern names for the country in European languages are derived more directly from the name of the Habesha." The post-classical Latin forms "Abyssina" or "Abassina" are attested in 1577 or earlier; the place name "Abyssinia" and its variants appear in English materials from the second half of the seventeenth century. Given the theme of this article, it is worth noting with the $O E D$, lastly, that "the first cat known to have been described as Abyssinian was apparently brought back from India by an army officer and exhibited at a cat show in London in 1872".
} 
The linguistic and racial affinities, in particular, are relevant to the putative connections that Jones draws between India and Ethiopia. Earlier in the discourse, Jones stated briefly that "the inscriptions at Canárah ... seem to be compounded of Nágari and Ethiopick letters, which bear a close relation to each other, both in the mode of writing from the left hand, and in the singular manner of connecting the vowels with the consonants" ${ }^{\text {. Jones now }}$ reiterates the similarity in letters and uses the affinity to claim that Ethiopia and India "were peopled or colonized by the same extraordinary race". This claims he validates by pointing to alleged racial similarities between Abyssinians and people who live on mountains in Bengal and Bihar. Jones seeks, notably, confirmation of the Indo-Ethiopic connection in ancient Greek and Latin authors such as Strabo and Apuleius - the recourse to antiquity is significant, as we shall see later.

Jones returns to the linguistic connections in subsequent discourses and again he groups the Ethiopians and Egyptians with the Indians, Persians, Greeks, and Romans. In the Eighth Anniversary Discourse, delivered in Calcutta on 24th February 1791, Jones says that "the written Abyssinian language, which we call Ethiopick" is not just related to Arabic, Hebrew, and "Chaldean", but also uses characters that are similar to those found in Indian languages ${ }^{7}$. The Ethiopian letters resemble the letters of the Devanagari script, according to Jones, and "had at first a similar form". He goes on to argue that the Ethiopians and the Egyptians were originally one people and these in turn were the same as the original Indians ${ }^{9}$. Again in this discourse, Jones shows an awareness that Ethiopians and Indians were confused in Greek and Roman antiquity; he postulates that the ancient Greeks referred both to the "southern nations of Africk" and to the people of India as Indians and that they used Indian and Ethiopian "as convertible terms"10. Jones has no hesitation in arguing that Ethiopians and Indians were one and the same people in the distant past, and it seems to him that the ancient practice bolsters his case for the primal unity of the nations.

\section{The Bible and Ethnology}

How should we understand Jones' remarks about the connection between Ethiopia and India? Thomas Trautmann has shown that one framework in which we can place Jones' writings is ethnological. Trautmann refers to the framework as a "Mosaic" ethnology since its "frame is supplied by the story of the descent of Noah in the book of Genesis, attributed to Moses, in the Bible"11. The ethnological framework, which in its various versions proved to be extremely influential among European thinkers well into the Enlightenment and beyond, gained its specificity from the genealogies mentioned in the Bible and especially in Genesis.

${ }^{6}$ Ibid, pp.35-36.

${ }^{7}$ Ibid, p. 166.

${ }^{8}$ Ibid.

${ }^{9}$ Ibid, p. 167.

${ }^{10}$ Ibid, p. 169.

${ }^{11}$ Thomas R. Trautmann, Aryans and British India (Berkeley: University of California Press, 1997. Reprint, Delhi: Yoda Press, 2004), p.41. 
According to chapter 10 of Genesis, Noah had three sons, Shem, Ham, and Japheth, and these in turn had further offspring: Ham is said to have Cush, Mizraim, Put, and Canaan as his sons, for example, and Cush in turn was the father of Seba, Havilah, Sabtah, Raamah, Sabteka, and Nimrod. Jones is unable to shake off the influence of the Mosaic ethnology on his thinking, and he attempts to reconcile his own observations with biblical ethnology as he perceives it.

In taking over the ethnologies of the Bible, Jones followed in the wake of Isaac Newton's The chronology of ancient kingdoms amended (1728) and, especially, Bryant's Analysis of ancient mythology, which were revisions of older conceptions of biblical ethnology. As Trautmann has argued, Jones does not unilaterally accept the reasoning given by Newton and Bryant, nor does he quite follow their methodologies; Jones does, however, agree with many of their conclusions. His main exposition comes in the Ninth Anniversary Discourse, "On the Origin and Families of Nations", delivered in Calcutta on 23rd February 1792, though much of the thinking that went into this paper evidently informed the earlier discourses. Following his reading of the Mosaic ethnology, Jones divides up the peoples of the world into three groups, which, in his view, originally came out of Iran. These three groups he calls the Indian, the Arabian, and the Tartar. The Indian group is descended from Ham, the Arabian from Shem, and the Tartar from Japheth. The Indian group consists of Indians, Persians, Romans, Greeks, Goths, "the old Egyptians or Ethiops", and probably Chinese and Japanese ${ }^{12}$. The Arabian group consists of Jews, Arabs, Assyrians, people who spoke Syriac, and Abyssinians. The Tartars differed from the other two groups, dispersed far and wide, and are harder to reconstruct but include the "Sclavonians". Jones' innovation, following Bryant, lies in claiming that the Greeks, Romans, Indians, Persians, Egyptians, and Ethiopians all are descended from Ham, whereas previous commentators placed the Greeks and Romans in a line from Japheth and not from Ham; his other innovation is to emphasize the importance of Indians and Persians in the group descended from Ham.

Jones' further remarks on the descendants of Ham and their relationships are revealing. He writes that the biblical figures Cush, Misr, and Raamah have counterparts in Sanskrit narratives. The biblical Cush or Cus (son of Ham) is parallel to Kusa, the son of Rama; the biblical Misr or Mizraim (also a son of Ham) is parallel to the familiar Indian name Mishra; and the biblical Raamah (son of Cush) is parallel to Rama. Jones seeks to support these arguments by discerning other similarities between early books of the Bible and Sanskrit texts and says that versions of the biblical flood, the Tower of Babel, and the scattering of peoples and nations can also be found in the Puranas, among other texts. He tells us further, in the Ninth Discourse, that the descendants of Ham invented letters, identified heavenly bodies such as stars and planets, and calculated the Indian period of 432,000 years ${ }^{13}$.

These peoples dispersed over land and sea: the tribes of Misr, Cush, and Rama settled in India and Africa, while some of this family passed through Egypt, Phoenicia, and Phrygia

${ }^{12}$ Jones, The Works of William Jones, 3. p.186.

${ }^{13}$ Ibid, p.202. 
into Italy and Greece, some moved into Scandinavia, some into Kashgar and Eighur, Khata and Khotan, and others indeed into Mexico and Peru, where literature and mythology similar to those found in Egypt and India have been discovered ${ }^{14}$.

Of these connections and dispersions, it is significant that Jones groups the names of Cush, Misr, and Rama together and posits a relatively close connection between the peoples associated with the three. To twenty-first century critics, the connection seems implausible, not least because it unites language families that modern linguists keep apart, namely, the Afro-Asiatic (which encompasses Egyptian and Ethiopian languages) and the IndoEuropean (which includes Sanskrit). But Jones and other contemporaries were open to the possibility that Egypt, Ethiopia, and India were somehow linked to each other in antiquity and devoted a considerable amount of energy to establishing such a link. There was no inconsistency to them in seeing a nation so culturally and geographically remote as India mentioned in the Hebrew Bible. They believed the Bible had an explanatory value that was historical and ethnographic as well as religious and they supposed that texts from distant cultures appeared to corroborate the apparent affiliations made by the Hebrew scriptures.

As the triad of names indicates, moreover, Egypt (Mizraim in Hebrew, Misr in Arabic) obsessed the Indian Orientalists no less than Ethiopia, perhaps even more than Ethiopia, and several writers sought to show that the ancient Indians derived their learning from Egypt or, vice-versa, that the Indians transmitted their lore to the Egyptians. But Egypt and Ethiopia implied different histories to these writers, and Ethiopia was a less stable category than Egypt in geographic and perhaps ethnologic terms. Well before Jones' presented his discourses to the Asiatic Society in Calcutta, Nathaniel Brassey Halhed composed a Grammar of the Bengal Language (1778) in which he held out the prospect of an historic exchange between Egypt and India. Halhed knew of an Indian raja who owned Sanskrit manuscripts "which give an account of a communication formerly subsisting between India and Egypt; wherein the Egyptians are constantly described as disciples, not as instructors, and as seeking that liberal education and those sciences in Hindostan, which none of their own countrymen had sufficient knowledge to impart. The few passages which are extant in the antient Greek authors respecting the Bracmans at the same time that they receive a fresh light from this relation, very strongly corroborate its authenticity"15. A few years later, James Burnett (Lord Monboddo) proclaimed that Sanskrit and Greek were dialects of the ancient Egyptian language, which Osiris had conveyed to India and which was the oldest language in the world ${ }^{16}$. Ethiopia was thus part of a group that included Egypt and India, and while it did not have the lure of hieroglyphs and pyramids, Ethiopia, like Egypt, had an antiquity and a biblical pedigree that made it an attractive part of the fantasies of the Indian Orientalists.

\footnotetext{
${ }^{14}$ Ibid, p.203.

${ }^{15}$ Nathaniel Brassey Halhed, A Grammar of the Bengal Language (Printed at Hoogly in Bengal, 1778), p.V.

${ }^{16}$ Monboddo, Lord [Burnett, James]. Antient Metaphysics: or, The Science of Universals. 6 vols (Edinburgh: T. Caddell, 


\section{The Orientalists: Francis Wilford}

The triangulation of India, Egypt, and Ethiopia was given an elaborate and colourful explication by Francis Wilford (who was born in 1751 or 1761 and died in 1822), a man known to Jones and "an eccentric subaltern in the army of Orientalism" 17 .

Thanks to the analyses of Chris Bayly, Nigel Leask, and Trautmann, we are well informed about Wilford's activities and the reception of his speculations ${ }^{18}$. Wilford served as an assistant to the Surveyor-General in India from 1786 to 1790 when he drafted military maps in Bihar. He retired from the army in 1794 and settled in Benares, where he was Secretary to the Committee of the Sanskrit College. He married Khanum Bibi Sahib, an Indian woman, with whom he had daughters who married into the ranks of the East India Company. Wilford seemed to have a knack for obtaining and discovering Sanskrit manuscripts, which he passed on to Orientalists. "He employed a large staff of Pandit copyists and translators and had become 'brahminised' according to a later reformist Hindu traveller", and he was himself the unfortunate victim of a deception practised on him by his head pandit ${ }^{19}$.

"If not today's 'Black Athena'," Bayly writes, "he would certainly have recognised 'Asian Athena" "20. Wilford's first major statement on the connection between north-east Africa and India appeared in volume 3 of the Asiatick Researches under the heading "On Egypt and other Countries, Adjacent to the Ca'li' River, or Nile of Ethiopia, from the Ancient Books of the Hindus". Wilford draws loosely on the Puranas but arrives at an understanding of them that differs markedly from the conceptions of his contemporaries and of later scholars. A large part of the work is based on etymological connections and linguistic analysis that many would find far-fetched, implausible, or bizarre. A small group of writers did adopt Wilford's interpretation of the relationship between Africa and India, however, and his essays "exerted a powerful influence on early nineteenth-century antiquarians and Romantic poets like S. T. Coleridge, Robert Southey, Tom Moore, and Percy Shelley"21. The details and implications of his work are worth considering at least briefly.

Wilford presents his long article in the Asiatick Researches as an exercise in comparative geography, but the work is as much about allusion and etymology as it is about geography. We may summarize part of it in the following way. The Puranas relate that Satyavrata, who survived a great deluge, had three sons, Sharma, Charma, and Jyapeti. Satyavrata curses his son Charma since the latter laughs at the old man when he becomes accidentally drunk on a strong liquor of fermented rice. As a result of his father's curse, Charma becomes a slave to the slaves of his brothers ${ }^{22}$. The children of his brother Sharma come to a settlement on

\footnotetext{
${ }^{17}$ Christopher Bayly, Orientalists, informants, and critics in Benares. In Perspectives of Mutual Encounters in South Asian History: 1760-1860, ed. by Jamal Malik, 97-127 (Leiden: Brill, 2000),p.104.

${ }^{18}$ Ibid, Nigel Leask, Francis Wilford and the colonial construction of Hindu geography, 1799-1822. In Romantic geographies: Discourses of travel 1775-1844, ed. by Amanda Gilroy, 204-222, (Manchester: Manchester University Press, 2000); Trautmann, Aryans and British India.

${ }^{19}$ Bayly, Orientalists, Informants, and Critics in Benares, p.103.

${ }^{20}$ Ibid, p. 104.

${ }^{21}$ Leask, Francis Wilford and the Colonial Construction of Hindu Geography, p.205.

${ }^{22}$ Francis Wilford, "On Egypt, and Other Countries adjacent to the Ca'li' River, or Nile of Ethiopia. From the Ancient Books 27 of the Hindus," Asiatick Researches 3 (1792): 295-468.pp.312-13.
} 
the banks of the river Nila, or Cali, in Egypt, where after acts of pious devotion they build a pyramid and then seek refuge in the mountains.

The descendants of Sharma can be found in the mountains of north India and Ethiopia. The pyramid, or Padma-Mandir, is probably in the town known to the Greeks as Byblos in Egypt. The source of the Nila lies in the land of Sharma, a land also known by its name Sharma-Sthan, and it includes Ethiopia along with parts of Abyssinia and Azan.

Since Charma laughed at his drunk father, according to Wilford, he was given the name Hasyasila (the "Laugher") and his descendants are called Hasyasilas and even Habashis ${ }^{23}$. (Wilford has in mind the Arabic word "Habashi", from which derives the Indo-Persian term "Habshi", which denotes Ethiopians, Abyssinians, or East Africans generally.) The Hasyasilas are the same as the Cutila-césas or they are a branch of the Cutila-césas who settled on the banks of the Nile and were expelled from Egypt and dispersed over African deserts. The Gaituli, who are also mentioned in classical authors, are the descendants of the Cutilas. The Cutila-césas lived originally in Bengal. "They were black, and had curled hair, like the Egyptians in the time of Herodotus: but at present there are no such negroes in India, except in the Andaman Islands ..."24. Wilford adds, "It is certain, that very ancient statues of Gods in India have crisp hair, and the features of negroes . . . I have seen many idols on which the woolly appearance of the hair was so well represented as to preclude all doubt" 25 . These statues were made by the Cutila-césas when they enjoyed power in India.

Wilford is deeply interested in the racial connection between Indians and black Africans; he disagrees with the Brahmans who consider that these statues of gods were created by Buddhists and points to the "thick lips and flat noses of those ancient images" 26 . He is convinced that "a race of negroes" ruled in India at some early stage in history and observes that mountaineers in his own time "still have some resemblance to negroes in their countenance and hair, which is curled, and has a tendency to wool" 27 . Though they have changed through intermarriage with others who may be black and have straight hair. Wilford also comments on the Syama-muchas, another group that migrated from India in ancient times. These have black faces and straight hair, like the Hindus who live on the plains, and in his view are "the straight-haired Ethiops of the ancients, and their king, surnamed Mahasyama, or the Great Black, was probably the king ARABUS, mentioned by the Greek mythologists"28. For Wilford, the racial evidence indisputably points to a close kinship between the Ethiopian and Indian peoples.

Another of Wilford's claims is that the Sanskrit word Cusha-dwipa (the conventional modern transliteration is Kushadvipa) is an ancient name for Ethiopia, the land of Cush. As Wilford correctly observes, the Puranas divide the world into seven $d$ wipas or concentric

\footnotetext{
${ }^{23}$ Ibid, p.331.

${ }^{24}$ Ibid, p.355.

${ }^{25}$ Ibid.

${ }^{26}$ Ibid, p.356.

${ }^{27} \mathrm{Ibid}$.

${ }^{28}$ Ibid.
} 
islands, one of which is Cusha-dwipa. In Wilford's own reading, however, the island extends from the Mediterranean to the borders of India. According to him, a further division of the globe adds six dwipas, including another Cusha, which is described as Cusha-dwipa without and to be regarded as different from the former, which is Cusha-dwipa within. Sanskrit scholars typically explain Kushadvipa from "kusha grass".

\section{But Wilford writes,}

CUSHA-dwípa without is Abyssinia and Ethiopia; and the Brahmens account plausibly enough for its name, by asserting, that the descendants of CUSHA, being obliged to leave their native country, from them called Cushadwípa within, migrated into 'Sanc'ha-dwip, and gave to their new settlement the name of their ancestor; for, though it be commonly said, that the dwipa was denominated from the grass Cuśha, of the genus named Poa by LINNÆUS, yet it is acknowledged, that the grass itself derived both its appellation and sanctity from CUSHA, the progenitor of a great Indian family: some say that it grew on the valmíca, or hill formed by Termites, or white ants, round the body of CUSHA himself; or of CAUSHICA, his son, who was performing his tapasyá, or act of austere devotion; but the story of the ant-hill is by others told of the first Hindu poet thence named VA'LMI'CA.

(Wilford 1792: 302)

In this account, Cusha-dwipa without is formed by settlers from Cusha-dwipa within, and the standard explanation from grass is given a twist so that it becomes subordinate to what is here Wilford's main claim, the reference to Abyssinia and Ethiopia in the Puranas.

Wilford uses the term Sancha-dwip probably to refer to Egypt, but to him Egypt also has other names in the Sanskrit books including Misra-sthan, Misra, and Misrena ${ }^{29}$. Brahma himself bears the title Misreswara. The Arabic word Misr, for Egypt, is derived from the Sanskrit, but the Hindus now appear to have forgotten the origin of the word and use it to denote any large city or a boundary or line of separation. Further, Herodotus' views about the Delta and the formation of Egypt are paralleled in the Puranas, which give their own account of the geological changes that are said to have resulted in the silting of the Delta and the creation of the country ${ }^{30}$. In Wilford's view, lastly, the Sanskrit texts also refer to various Egyptian cities such as Thebes and Memphis and to Lake Moeris.

Wilford argues his case with even greater complexity and determination than these extracts suggest, but, rather than go deeper into his hypotheses, let us turn to the remarks that Jones makes in grudging defence of Wilford's article. Here, as before, Jones also evinces the desire "to assimilate the cultural heterogeneity of India into the metanarratives of European universal history and geography" ${ }^{31}$. Jones' words are printed immediately after Wilford's article in the same volume of the Asiatick Researches. He translates two Sanskrit passages that Wilford quotes and that are ostensibly from the Puranas: the first, in Jones' view, "is a little poem, in the form of the hymns ascribed to ORPHEUS, in praise of the Nilá, which all the Bráhmens allow to be a sacred river in Cusha-dwip, and which we may confidently pronounce to be the Nile"32.

\footnotetext{
${ }^{29}$ Ibid, p.337.

${ }^{30}$ Ibid, p.338.

${ }^{31}$ Leask, Francis Wilford and the Colonial construction of Hindu Geography, p.205.

${ }^{32}$ Wilford, "On Egypt, and Other Countries Adjacent to the Ca'li’ River", p.463.
} 
The second passage is said to come from the Padma Purana and is about Satyavarman or Satyvrata, the father of Sharma, Charma, and Jyapeti. Jones compares the passage to "the Mosaic relation of the same adventure" and approves the identification of Satyvrata "with the NOAH of Scripture" "33. Jones concludes by agreeing with Wilford on many points, including the notion that the ancient Indians had knowledge of Egypt and the Nile ${ }^{34}$.

Wilford had relied on Pandit Vidyananda to supply him with many of his Sanskrit materials, but the pandit turned out to be an unreliable source since he faked many of the manuscripts and made alterations to existing texts; the pandit was possessed of a skill so accomplished that he composed some 12,000 new verses in one instance ${ }^{35}$. Wilford acknowledges the problems with his source in volume 8 of the Asiatick Researches but does not quite retract the entirety of his arguments about Egypt and Ethiopia. The passages provided by the pandit contained "much truth", Wilford notes, and the learned reader should not be in doubt that the overall conclusions he draws in that article are correct. The story of Noah and his three sons may well be a fabrication and may not occur verbatim in the Puranas: but Wilford goes on to say that the story occurs "in less explicit terms" in the Puranas and so should not be discounted in its entirety ${ }^{36}$. Even though the pandit inserted the name of Egypt into many Sanskrit manuscripts, the overall weight of the myths and legends quoted by the pandit and by Wilford was proof to him of the connections and affinities that existed between Africa and India in antiquity. Wilford thus holds on to the basic outlines of his arguments about Egypt and Ethiopia and indeed goes on to argue that Hindus in ancient India worshipped the British Isles.

Bayly makes the point that rather than think of Wilford or Jones as naive, we should recall their attitudes to antiquity and the Bible. Men such as Wilford "felt that almost everything was once known by the Ancients and that Humanity's common store of knowledge was implanted by Providence at the beginning of time, before the Flood fragmented its pristine unity"37. What is clear is that while men such as Wilford gave the impression that they were interested in validating the Bible, they were able to use the Bible in order to justify their enquiries into Hinduism, Mughal India, and Indian history and argue that their work was relevant to the study of Christianity. They were emphatically not like the British evangelicals and missionaries of the nineteenth century who sought to convert Indians to Christianity and who were disdainful of Hinduism, Islam, and Buddhism. They consulted local experts in Hindu, Islamic, and other scriptures and listened to them at great length. For these Orientalists, the Bible was deployed to promote scholarly enquiry into the Sanskrit and Indo-Persian traditions of South Asia and not, at least not explicitly, as a textual justification for the superiority of Christianity.

\footnotetext{
${ }^{33}$ Ibid, p.466.

${ }^{34}$ Ibid, p.467.

${ }^{35}$ Rosane Rocher and Ludo Rocher, The Making of Western Indology: Henry Thomas Colebrooke and the East India Company (London: Routledge, 2012), p. 76; Francis Wilford, "An Essay on the Sacred Isles in the West, with other Essays connected with that Work," Asiatick Researches 8 (1805): 245-367.

${ }^{36}$ Wilford, "An Essay on the Sacred Isles in the West", p. 254.

${ }^{37}$ Bayly, Orientalists, Informants, and Critics in Benares, p.106.
} 


\section{Race, Slavery, and the Bible}

In this context, the fraught relationship between the Hebrew Bible and black slavery is worth mentioning. The major text on this point is Genesis, here in the King James Version, with the spelling modernized:

And Noah began to be an husbandman, and he planted a vineyard. And he drank of the wine, and was drunken; and he was uncovered within his tent. And Ham, the father of Canaan, saw the nakedness of his father, and told his two brethren without.

And Shem and Japheth took a garment, and laid it upon both their shoulders, and went backward, and covered the nakedness of their father; and their faces were backward, and they saw not their father's nakedness. And Noah awoke from his wine, and knew what his younger son had done unto him. And he said, Cursed be Canaan; a servant of servants shall he be unto his brethren.

Genesis 9.20-25

The passage from Genesis does not refer to Ham or his descendants as black but it is nonetheless a text invoked frequently in the modern period to justify black slavery. The roots of this usage go back to antiquity. Between the second and fourth centuries $\mathrm{CE}$, Jewish authors begin to think of Ham as black; by the sixth or seventh century, the view was becoming entrenched that Ham, the ancestor of black Africans, was cursed with slavery. By the early modern period, a number of Christian, Muslim, and Jewish sources took the view that the slavery of black Africans could be explained through the curse that Noah put on Ham and his descendants ${ }^{38}$. As John Weemes wrote, in 1627, “. . . this curse to be a servant was laid, first upon a disobedient sonne Cham, and wee see to this day, that the Moores, Chams posteritie, are sold like slaves yet" 39 . In the late eighteenth century, when Jones and Wilford were writing, the association between the curse of Ham and black slavery would have been familiar to most European men of letters and certainly to figures who were versed in biblical interpretation and ethnology.

Race, slavery, and the Bible had intersected in powerful ways long before Jones and Wilford arrived in South Asia and would have shaped the contexts in which they investigated Indian culture and history. Jones, for one, seems to have adopted a somewhat inconsistent attitude toward slavery. Before he went to Calcutta, Jones "condemned the African slave trade with a passion that impressed Wilberforce", and yet in Calcutta he was prepared to defend domestic slavery and appeared to think of household slaves as domestic servants ${ }^{40}$. He seems to accept the impositions of the British Empire and the practice of slavery in colonial Bengal, despite the vehemence of his earlier stance. Perhaps, he is drawing a distinction between the trade in African slaves and the established customs of domestic slavery in India? "I have slaves, whom I rescued from death or misery, but consider them as other servants, and shall certainly tell them so, when they are old enough to comprehend the difference of the terms" $"$.

\footnotetext{
${ }^{38}$ David M. Goldenberg, The Curse of Ham: Race and Slavery in Early Judaism, Christianity, and Islam (Princeton: Princeton University Press, 2003).

${ }^{39}$ John Weemes [Weemse], The Pourtraiture of the Image of God in Man (London: Printed for Iohn Bellamie, 1627), p.279.

${ }^{40}$ Michael J. Franklin, Orientalist Jones: Sir William Jones, poet, lawyer, and linguist, 1746-1794 (Oxford: Oxford University Press, 2011), pp. 294-95.

${ }^{41}$ Jones, The Works of William Jones, 7.p.15; Franklin, Orientalist Jones, p.295.
} 
In condemning the trade in African slaves, he seems to be upholding the rights of black Africans to be free; in himself keeping Indian slaves, he seems to be denying Indians the right to be free. This attitude undercuts the racial and historical connections he discerns between Africans and Indians; it is seemingly at odds with his belief that Indian culture is highly accomplished and civilized. It may be that what he finds abhorrent about African slavery is its viciousness, violence, and brutality, which he may not perceive regularly in the "domestic" slavery he accepts in Calcutta.

In condoning slavery in India, he may feel that he is accepting a custom that has been prevalent in Indian society long before the arrival of the British. If he is guilty of moral and political compromises, his overall position on the subject is complicated: for all his prevarications, as Michael Franklin observes, "Jones had been instrumental in the abolition of the Bengal slave trade almost two decades before the 1807 act outlawed the trade throughout the British Empire"42. Jones' stance toward race and, in particular, the race of Indians is shaped by inherited attitudes and colonialism but also coloured by his desire to understand the history of the people among whom he lives and works.

When Jones and Wilford comment on the racial affinities between Ethiopians and Indians, they frequently draw attention to the shared blackness of the two peoples. The racial distinction between Indians and Ethiopians is, thus, regularly blurred, challenged, or even discarded in the writings of these authors. One way of interpreting the idea of a racial continuum that unites Ethiopians and Indians is to say that the separation between "Oriental" and "black" is not easy to make in the eighteenth century. Felicity Nussbaum notes that "representations of people of colour in the eighteenth century mutate through the spectrum of tawny, sallow, olive, mulatto, sooty, and ebony - of East Indian, West Indian, American Indian, Pacific Islander, and North and sub-Saharan African, all of whom are at times designated in British (if not American) parlance as 'black'"43.

We may, with Nussbaum, point to the turbaned Moor as the example of a literary character whose exact complexion varies according to author and genre and who has the ability to slip in and out of a vast zone of exoticism that stretches from North Africa through the Middle East and up to India. Orientalism and racial theories thus join together to conjure up a fluid idea of the Moor who is as much at home in North India as in North Africa: "For the Renaissance and much of the eighteenth century, the Moorish prince, often turbaned, who is fixed in rank but subject to enslavement, represents a kind of swing figure between sexualities, skin colours, and sometimes religions"44.

The Ethiopians and Indians of Jones and Wilford seem in many instances to conform to this idea of a generalized black who is also Oriental or generalized Oriental who is also black.

\footnotetext{
${ }^{42}$ Franklin, Orientalist Jones, p. 300.

${ }^{43}$ Felicity A Nussbaum, Between 'Oriental' and 'Blacks So Called', 1688-1788. In The Postcolonial Enlightenment: Eighteenth-Century Colonialism and Postcolonial Theory, ed. by Daniel Carey and Lynn Festa, 137-166 (Oxford: Oxford University Press), p.143.

${ }^{44}$ Ibid, pp.146-47.
} 
While the idea that Indians are "black" is rife in European literature of many periods including the eighteenth century, English authors also comment on Indians who desire not to be called "black" or "negro" themselves. Of the area around Madras and the Coromandel Coast, Edward Ives writes, in the eighteenth century, "The natives on this coast are black but of different shades. Both men and women have long shining black hair, which has not the least tendency to wool like that of the Guinea Negroes. You cannot affront them more, than to call them by the name of negroe, as they conceive it implies an idea of slavery"45.

We cannot tell, from such accounts, how or whether the Europeans and Indians overcame linguistic, cultural, and historical barriers and discussed racial matters or slavery. These are complex narratives in which Europeans who comment on the complexions of natives say that the natives themselves are given to racial hierarchies. What Ives implies is that Indians are sensitive to racial issues and are wary of being compared to black African slaves, many of whom had come from Ethiopia.

\section{Ethiopians in India}

Behind the claims that the British Orientalists make about Ethiopia and India lies, in fact, the deep history of contact between Ethiopia and India. According to one source, William Jones himself conversed with an Ethiopian who was his guest in India ${ }^{46}$. Abu Rumi, an Ethiopian and a translator of the Bible, travelled via Syria and Persia to India and stayed in Jones' house in Calcutta for a while; he then went on to Mocha before he returned back to Ethiopia. Whether Abu Rumi and Jones discussed Jones' theories about the similarities between Ethiopian and Indian culture is anyone's guess. Abu Rumi is one of a large number of Ethiopians who came to India, however, and the history of Ethiopians in India extends back centuries before Jones. Ethiopians were brought to India, often forcibly, before and after the British East India Company established itself in the area ${ }^{47}$. Ethiopians were known to Indians variously as Habshis, Sidis, and kaffirs: Habshi, from Habash, the Arabic for "Abyssinia"; Sidi, probably from the Arabic Saiyid or "master"; and kaffir, from the word for "non-believer". That these names were sometimes applied indiscriminately to Africans and not solely to Ethiopians should not detract from the significance of the large numbers of Ethiopians who were taken to India over centuries. (In India, today, "the word habshi is often heard applied in a pejorative sense to an Indian of dark skin, and also frequently to a man of Gargantuan appetite" 48 .

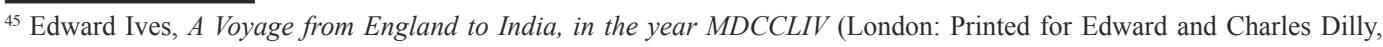
1773), pp.22-23.

${ }^{46}$ William Jowett, Christian Researches in the Mediterranean, from MDCCCXV to MDCCCXX. In furtherance of the objects of the Church Missionary Society (London: Published, for the Society, by L. B. Seeley, and J. Hatchard \& Son, 1822 ), p.201. ${ }^{47}$ Burton-Page, J. "Habshī." In Encyclopaedia of Islam, 2nd edn., edited by P. Bearman, Th. Bianquis, C. E. Bosworth, E. van Donzel, W. P. Heinrichs, vol. 3, 14-16 (Leiden: Brill, 1954-2002); Richard Pankhurst, The Ethiopian Diaspora to India: The Role of Habshis and Sidis from Medieval Times to the End of the Eighteenth Century. In The African Diaspora in the Indian Ocean, ed. by Shihan de S. Jayasuriya and Richard Pankhurst, 189-222 (Trenton, New Jersey: Africa World Press, 2003); Amy Catlin-Jairazbhoy and Edward A. Alpers, eds. Sidis and Scholars: Essays on African Indians (Trenton, New Jersey: Red Sea Press, 2004); Kenneth X.Robbins, and John McLeod, eds. African Elites in India: Habshi Amarat (Ahmedabad: Mapin, 2006); Sylviane A., Diouf, and Kenneth X. Robbins, Africans in India: From Slaves to Generals and Rulers. NYPL Point, volume 2, edition 2, 2013. Available online at: http://www.nypl.org/point.

${ }^{48}$ Burton-Page, "Habshī." In Encyclopaedia of Islam; Nilanjana S. Roy,"A Racist Turn in India." The New York Times (26 January 2014), p. SR10. Also at: http://nyti.ms/1eXF3eJ.
} 
Ibn Battuta comments on the presence of Habshis across many parts of India during his travels in the region in the fourteenth century. By the end of that century, significant numbers of Habshis are attested in Gujarat by historical sources, and soon after they are attested in Bengal and the Deccan as well. "The flow of Habshi slaves into India continues through the Mughal period, and the names of individual Habshis occur frequently throughout the Mughal histories"49. The historian known as Haji ad-Dabir, who completed his history of Gujarat in Arabic by about 1605, comments on the numbers of Abyssinians in the region in the fifteenth century. "He claims that they were as good as Arabs in everything except descent, but were often disliked by ordinary Indians, who were sometimes incited to murder them" 50 . Among Habshis who attained high rank are Atish Habshi, governor of Bihar and then the Deccan, and Dilawar Khan, another governor of the Deccan. In Gujarat, they served as soldiers and sailors, "and their descendants are still recognized as a separate Muslim community".

The Orientalists' fascination with race and skin colour can also be found in Indians' accounts of Ethiopians in India. These observations on the race of Ethiopian slaves and soldiers are of a very different tenor from what we find in the Orientalists and their concern with languages and civilizations. They vary considerably. The Mughals' remarks about the race and colour of Ethiopian slaves contrast with western Deccan attitudes toward them. According to Richard M. Eaton, "dominant sections of the Mughal ruling class cultivated a posture of racial arrogance, a strong sense of pedigree, and a sense of hereditary aristocracy not found in the Deccan"51. In his memoir, the Mughal emperor Jahangir, who ruled from 1605 to 1627, refers to one of his enemies, Malik Ambar, a Habshi, as "black-faced", "of dark fate", and "the black-fated one", while his soldiers are "the rebels of blackfortune" 52 . The Deccan sultanates, however, were home to mixed communities, including populations of Ethiopians, Iranians, Central Asians, Arabs, Marathas, and an old Deccani nobility that traced its ancestry back to Indo-Turkish populations. "This motley collection of communities contrasted with the more homogenous ruling class of Mughal north India, which throughout the sixteenth and seventeenth centuries received continuous infusions of blue-blooded Persian-speaking immigrants — mainly Iranians or Persianized Turks_-from nearby Iran and Central Asia"53.

A number of historians and other writers remark on the skill, bravery, and strength of the Ethiopians who served in the armies of native rulers. One of Jahangir's own historians writes in laudatory terms of Malik Ambar on the news of Ambar's death: "In warfare, in command, in sound judgement, and in administration, he had no rival or equal . . History records no other instance of an Abyssinian slave arriving at such eminence"

\footnotetext{
${ }^{49}$ Burton-Page, "Habshīi." In Encyclopaedia of Islam.

${ }^{50}$ Pankhurst, The Ethiopian Diaspora to India, p.202.

${ }^{51}$ Richard M. Eaton, The Rise and Fall of Military Slavery in the Deccan, 1450-1650. In Slavery and South Asian History, ed. by Indrani Chatterjee and Richard M. Eaton, 115-135 (Bloomington: Indiana University Press, 2006), p.122.

${ }^{52}$ Ibid, p.127.

${ }^{53}$ Ibid, p. 122.

${ }^{54}$ Elliot, Sir H. M. The History of India, as Told by Its Own Historians: The Muhammadan Period, ed. [and continued] by John Dowson. 8 vols (London: Trübner \& Co., 1867-1877) 6. pp. 428-29; Richard M. Eaton, "The Rise and Fall of 34 Military Slavery in the Deccan; Jonathan Gil Harris, The First Firangis: Remarkable Stories of Heroes, Healers, Charlatans, Courtesans \& Other Foreigners Who Became Indian (New Delhi: Aleph, 2015).
} 
In the sixteenth century, Joam de Castro says that enslaved Ethiopians who serve as soldiers in India were "strong and valiant to such a degree that there was a proverb throughout India that good solders or ascaris, or servants, must be Abyssinian" well regarded in Bengal, Cambaia, Ballagate and other places that all those who command the armies or have a rank there are taken from this race" ${ }^{26}$. Near the end of the eighteenth century, J. H. Grose writes that Indian Muslims liked to have "Abyssinian" slaves, whom he supposed came from an area of Ethiopia that bordered on "Negroeland, in the heart of Africa"57. "Nothing can be imagined more smooth or glossy, and perfectly black than their skin, in which they far surpass the negroes on the coast of Guinea, and, generally speaking, have not anything of their thick lips, though otherwise as woolly haired as they. This species of slaves is, however, highly valued for their courage, fidelity, and shrewdness; in which they so far excel, as often to rise to posts of great trust and honor, and are made governors of places" $" 58$. Writers such as Grose and Kindersley show an eye for race and colour; they are also interested in assessing the "character" of the natives, their reputations for valour, their rank and station in society, and the attitudes of diverse natives to each other. Their writings may well be classified as ethnographic, at least in part, but the ethnography they practise is not related to the Bible or its genealogical elaboration.

It seems slightly odd that the Orientalists have little to say about the dense history of Ethiopians and other Africans in India or, what begins at a slightly later date, the history of South Asians in Ethiopia, when they write about the origins of races. Perhaps the intervening years between antiquity and the present were of little or no relevance to their theories. Other European commentators who spent any length of time in India were struck by the racial diversity of the area. At any rate, the wide diversity of races in India did not stop the British Orientalists from arriving at bold conclusions about race and racial origins in relation to India; rather, the Orientalists seem to have been spurred on to devise theories by the complexity of what they encountered in the Indian subcontinent. Jones seems to be saying that on the basis of perceived racial characteristics Ethiopians and Indians were once the same people, Wilford to be claiming that Ethiopians originated from black Indians. Do they, therefore, imply that all Indians were originally black or merely some of them? If only some were black, then why was there an original mixture of black and non-black Indians and from where did this mixed group come: from a Caucasian homeland or somewhere else? If all were originally black, then how and why did so many Indians become nonblack by the eighteenth century: was the diversity of race in South Asia the result of later intermarriage with outsiders or some other mechanism? Even in their own terms, the racial theories of Jones and Wilford raise more questions than they answer.

\footnotetext{
${ }^{55}$ Pankhurst, The Ethiopian Diaspora to India, p.200.

${ }^{56}$ Ibid.

${ }^{57}$ John Henry Grose, A Voyage to the East Indies; containing Authentic Accounts of the Mogul Government in general, the Viceroyalties of the Decan and Bengal, with their several subordinate Dependances. 2 vols (London: Printed for S. Hooper, 1772), p.148.

${ }^{58}$ Ibid. pp.149-50.
} 
It is worth remembering, nevertheless, that Jones and Wilford, and especially the former, would shape the views of numerous other thinkers in the nineteenth century, when scientific racism would be elaborated at great length.

\section{Antiquity and Modernity}

In order to understand how and why Orientalists such as William Jones were able to connect Ethiopia and India, it will help us to look at the ancient texts. Jones and Wilford were steeped in the texts of antiquity, especially Greek and Latin but also Hebrew. From this perspective, the name "Kush" or "Cush" (the latter is the Latinate spelling) is worth lingering over for a little longer: "Cush" is imprecise in the Hebrew Bible and remains imprecise when it is translated into "Ethiopia" by Greek and Latin authors. In the Bible, Cush or Cushite refers arguably to Nubia, south of Egypt, and the people who lived there, but the terms may denote the area and people on the south-west Arabian side of the Red Sea and at times seem to refer to Babylon or even Israel. When Jeremiah 13.23 says "Can the Cushite change his skin?", we are not exactly certain who or where the Cushite is, though most scholars take the name to refer vaguely to Nubians. The ancient Greek Bible renders the place name Cush as "Aithiopia" and the Latin Vulgate as "Aethiopia". The word "Cush" itself does not seem to appear in classical Greek or Latin authors. There are two exceptions: Genesis 10.6-8, a passage discussed above, where the Septuagint retains Xoú $̧$ to refer to the son of Ham and his family, and Judith 7.18, where the Septuagint uses Xoú to a village near Bethulia. English translations of the Bible generally follow the Greek and Latin authors, and the King James Bible, among other English versions, translates Cush into Ethiopia. (The situation is different in German. Martin Luther uses Mohr and Mohrenland in his translations from 1522 to $1545^{59}$. As a result of the transfer into Greek and Latin, and then also into English, Cush becomes identified with Ethiopia in many European traditions.

The Greek and Latin translation of Cush into Ethiopia does not help the term gain in specificity and, in many respects, confuses the referent even further. The relevant entry in the Oxford Classical Dictionary begins with the observation that "Ethiopia was a name applied by the Greeks to any region in the far south (but north of the equator)". Its borders were never really defined with real clarity in Greek or Roman antiquity. It is immensely significant, for our purposes, that Ethiopia and India are confused with each other from a very early date in Greco-Roman antiquity, that some ancient authors use "Ethiopia" when they appear to modern readers to be indicating India, that some use "India" when they appear to mean Ethiopia, and that some, despite the use of the proper noun, mean a place in neither Africa nor South Asia in any conventional sense. The referent for "Ethiopia" seems to move about from Africa, to Arabia, to India, and to places in between, depending on the author or text in question ${ }^{60}$.

\footnotetext{
${ }^{59}$ Lorenz Auf der Maur, "Ethiopia and Abyssinia in English”, p.525.
}

${ }^{60}$ T.K.Joseph, "Citerior India and Extra-Indian Indias-A Rejoinder," Journal of Indian History 25.2 (1947): 175-187; and T.K. Joseph, "India, a Continuation of Egypt and Ethiopia,” Journal of Indian History 26.2 (1948): 201-207. 
Scholars such as E. A. Schwanbeck, U. P. Arora, Klaus Karttunen, and Pierre Schneider have shown how all-pervasive the confusion remains in ancient sources: it extends to most genres and even to epigraphic texts ${ }^{61}$.

As Schneider demonstrates in his massive inventory, the confusion encompasses areas that we would think of as geography, ethnography, anthropology, myth, history, zoology, botany, and mineralogy. It also persists for centuries into late antiquity and beyond, in Christian and non-Christian authors. In late antique and Byzantine times, authors use the terms India maior and India minor, "Greater India" and "Lesser India": the former sometimes refers to the regions of Ethiopia, Arabia, and South Asia together, the latter to South Asia alone, but the names are also used inconsistently and ambiguously. The two Indias were occasionally also called India interior or ulterior and India exterior or citerior. By about $600 \mathrm{CE}$, pseudo-Abdias write of three Indias, a tripartite characterization that would later assume the names India prima, secunda, and tertia ${ }^{62}$. The confusion also exists in Syriac writings, including the Syriac translation of the Bible, and in targumic and medieval Jewish literature $^{63}$. The medieval accounts of Prester John belong to this history of confusion, as writers and travellers move his realm from India to an area south of Egypt. That there is a confusion is grasped, finally, by Renaissance humanists such as Hiob Ludolf (Job Ludolphus), but not investigated in detail until Schwanbeck in the middle of the nineteenth century, well after Orientalists such as Jones and Wilford write their works.

In fact, Jones and Wilford, whether deliberately or not, whether directly or indirectly, are responding to explicit claims that reach back to Greek antiquity. Speculation about the race and origins of Indians and Ethiopians occurs as early as Herodotus, who observes that Indians are "all black-skinned, like the Ethiopians". He adds: "Their semen, too, which they ejaculate into the women, is not white like other men's, but black like their skin, and resembles in this respect that of the Ethiopians" (3.101). In the next century, Aristotle corrects him on the colour of the Ethiopians' semen and affirms that all semen is white but, significantly, says nothing about Herodotus' other comments (History of Animals 2.2.736a). Numerous authors remark on the blackness of Ethiopians and Indians alike and attempt to discern variations, shades of blackness, and other differences in snub-noses and hair. Strabo, to whom Jones refers in the quotation above, says that southern Indians resemble Ethiopians (northern Indians resemble Egyptians) but their faces and hair are not similar;

\footnotetext{
${ }^{61}$ E.A. Schwanbeck, Megasthenis Indica. Fragmenta collegit, commentationem et indices addidit. (Bonn, 1846) 1-5, n.1; U.P. Arora, "India vis-à-vis Egypt-Ethiopia in Classical Accounts," Graeco-Arabica 1 (1982): 131-140 ; Klaus Karttunen, India in Early Greek Literature. Studia Orientalia, 65. (Helsinki: The Finnish Oriental Society, 1989); Pierre Schneider, $L$ 'Éthiope et l'Inde: Interférences et confusions aux etrémités du monde antique (VIIIe siècle avant J.-C.-VIe siècle après J.-C.) (Rome: École française de Rome, 2004); Pierre Schneider, The So-called Confusion between India and Ethiopia: The Eastern and Southern Edges of the Inhabited World from the Greco-Roman Perspective. In Brill's Companion to Ancient Geography: The Inhabited World in Greek and Roman Tradition, ed. by Serena Bianchetti, Michele Cataudella, and HansJoachim Gehrke, 184-202 (Leiden: Brill, 2015).

${ }^{62}$ Gianfranco Fiaccadori, “'India’ as name of Ethiopia.” In Encyclopaedia Aethiopica, vol. 3, edited by Siegbert Uhlig,

145-47 (Wiesbaden: Harrassowitz, 2007).

${ }^{63}$ Goldenberg, The Curse of Ham, p.211.
} 
later, he adds that Indians are not intensely dark since they live in a humid region and they do not have woolly hair (Geography 15.1.13). ${ }^{64}$ Arrian makes a similar point about the complexion, woolly hair, and snub-nosed appearance of southern Indians (Indica 6.9).

Even the idea that the Ethiopians were originally Indians and migrated to Africa finds an echo in the Greek and Latin texts. According to one character in Philostratus' Life of Apollonius of Tyana, an admittedly colourful narrative of the third century, the Ethiopians lived in India and migrated to their current area of habitation only later (3.2).

The conflation between the biblical Hebrew and the classical Greek and Latin materials reaches some kind of head already in the Etymologies of Isidore of Seville, who died in 636, and who wrote, "Ethiopians are so called after a son of Ham named Cush, from whom they have their origin. In Hebrew, Cush means 'Ethiopian'. This nation, which formerly emigrated from the region of the river Indus, settled next to Egypt between the Nile and the Ocean, in the south very close to the sun. There are three tribes of Ethiopians: Hesperians, Garamantes, and Indians" (9.2.127-28). In this text, the Ethiopians both have emigrated from the Indus valley region to Africa and also have a tribe known as "Indians". For Isidore, moreover, and as with the Orientalists, the dispersion of peoples is the result of the history narrated in the Bible: the Fall, the flood, and the Tower of Babel. One can trace human history backward to Adam and Noah or forward through the descendants of Ham, Shem, and Japheth and their offspring to the diverse peoples of the world. In other words, the Mosaic ethnology of the Bible is evident in early writers such as Isidore.

A couple of points, raised especially by Schneider, also explain the hold of the ancient confusion on later thinkers, into the Renaissance, when European knowledge of Ethiopia and India begins to increase exponentially. In the first place, the confusion between Ethiopia and India is not necessarily the result of a lack of geographical information. As we know, the association continues long after the Greeks and East Africans learned about the monsoons and weather patterns in the Indian Ocean in the reign of Ptolemy VIII and long after the start of trade between the Red Sea regions and the coasts of South India. The confusion is rooted deeply and cannot be shaken off easily, for a variety of reasons having to do with the conception of the world, spatial symmetries, the influence of literary traditions, and the persistence of old stereotypes; it as much a mode of thinking and a symbolic logic as a mistaken grasp of geographical realities. Secondly, the Ethiopians and Indians, in Schneider's analysis, form an ancient "ethnic community" of dark-complexioned people: the Ethiopians and Indians are bracketed together because they are perceived to share skin colour and because of the capacious understanding of an oikoumene in which black men in far flung places belong to one and the same group. Once the centripetal force of this "community" takes hold, Ethiopia and India become harder and harder to disentangle in the ethnologic and literary imagination of Greco-Roman authors.

\footnotetext{
${ }^{64}$ Jones also quotes from Apuleius in the passage above. Modern editors emend the Latin text at Metamorphoses 11.5 to which Jones appears to be referring: they read Aethiopes utrique ("the two Ethiopias") instead of Aethiopes Arique ("the

Arü and Ethiopians" in Jones and "the Arians and Ethiopians" in other translations).
} 
One of the notable features of the linkage is that it even continues long after observers come to think of Ethiopia as largely Christian and India as largely Hindu or largely Hindu and Muslim. The religious discrepancy is either explained away with further hypotheses or ignored altogether and scarcely affects the weight of the tradition.

Against the evidence from the Greek and Latin traditions, it is important to set down here that one of the names that ancient Ethiopians use for their own nation is 'Ityopya, which appears regularly from the fourth century CE. Aksumite writers were the first to use this Greco-Latin term to refer to their territories in the Horn of Africa. The word is doubtless an adaptation of the Greek Aithiops (Aïío\%), a name that the standard Greek-English Lexicon explains as "properly, Burnt-face, i.e. Ethiopian, negro". What seems remarkable is that the court at Aksum, whose elites were versed in Greek literature, adopts this expression "despite the fact that among Ethiopians themselves the skin does not stand out as either "burnt" or "black," but appears wholly unexceptional"" As Daniel Selden remarks, "one can only be Aithiops from the perspective of the pale Other"66. Selden also makes the important point that when Ethiopian writers mention their skin, they refer to it as 'addāmāwi, "of Adam's [i.e., human] color", a pun on "earth-toned" and "pleasant, agreeable, beautiful, fair"67. The Aksumites seem to have knowingly taken over the Greco-Latin name and to have inserted themselves strategically into the histories of the Greeks and Romans, Jews and Christians.

\section{Conclusion}

Orientalists such as William Jones and Francis Wilford made bold claims about Ethiopia and India, but their seemingly wild speculations built on beliefs or values held for centuries. The kinds of theories they proposed were not unusual in the late eighteenth century and were remarkably influential in the nineteenth century. Cultural contacts and exchanges of the kind they espoused were obsessions that went back to Renaissance humanists and further beyond to the ancient world. It was, moreover, pretty common for colonial administrators to seek out points of contact with world-historical figures or geographies known to them from classical Greco-Roman or Western sources. Alexander the Great was the foremost figure of this type, and, as Hegel noted, he provided a crucial fulcrum around which the histories of East and West, India and Europe, could be calibrated ${ }^{68}$. It was Jones himself who made the case for identifying Sandracottus of the Greek and Latin authors with Chandragupta Maurya and who thus offered another opportunity for conjoining the histories of ancient Greece and India. At first glance, Ethiopia and India appear to offer another kind of connection to observers based in Europe, a connection not of West and East, but perhaps of South and East, of north-east Africa and southern Asia. The connection, which is ostensibly racial, linguistic, and scriptural, offers a chance of thinking about non-European cultures.

\footnotetext{
${ }^{65}$ Daniel L. Selden, "How the Ethiopian Changed His Skin," Classical Antiquity 32 (2013): 322-377. p.334.

${ }^{66} \mathrm{Ibid}$.

${ }^{67}$ Ibid.

${ }^{68}$ Christopher A.Hagerman, "In the Footsteps of the 'Macedonian Conqueror': Alexander the Great and British India," International Journal of the Classical Tradition 16 (2009): 344-392; Pierre Briant, Alexandre des Lumières: fragments d'histoire européenne (Paris: Gallimard, 2012); Phiroze Vasunia, The Classics and Colonial India (Oxford: Oxford University Press, 2013).
} 
But it would be disingenuous to suppose that the proponents of the connection bypassed Greece, Rome, the Bible, or Europe and achieved a symbiosis between African and Asian cultures. The sovereign gaze was anchored firmly in a biblical, Greco-Roman, or European location, even or especially when the observers were resident in colonial Bengal.

An arresting feature of the confusion is that it seems to contradict a major development in linguistics by linking together the Indo-European and the Afro-Asiatic language families. But in the late eighteenth century, the Indo-European theory had not yet been worked out in detail, even by Jones, to whom it is credited, and older theories about the origin and dispersal of language still exerted a formidable hold ${ }^{69}$.

Once the Indo-European theory was elaborated, the yoking together of Ethiopia and India was harder to achieve, and indeed we see fewer and fewer serious attempts to tie the two cultures together after the middle of the nineteenth century. Another way of framing the problem of language is to say that race and nation are closely linked in the second half of the eighteenth century. The association between Ethiopia and India can be realized in the minds of Jones and Wilford, but it is notably accompanied by remarks about racial affinities between Ethiopians and some Indians. The racial connection is still used to justify an affinity between Ethiopians and Indians in the first half of the nineteenth century as the Indo-European hypothesis begins to take hold and, with it, the idea that Indo-European and Afro-Asiatic are distinct language groups. The joining of Ethiopia and India fades away, though not completely, by the end of the nineteenth century, by which point race and language are linked together in very different ways from how they were in the late eighteenth century.

Behind the claims and fantastic arguments of the Orientalists, there also appears a glimpse of Enlightenment universalism, the notion that peoples were formerly the same and were united by a common origin going back millennia. In the European Enlightenment, the conception was biblical, but not only biblical, and historians, philosophers, and travellers sought to devise a cosmopolitan framework in order to establish a set of values shared by all humankind. The Orientalists' idea that Ethiopians and Indians were once the same people goes back to antiquity but draws an added potency from this Enlightenment context. Enlightenment conceptions of universalism are, however, qualified by notions of the nation and nationalism, which begin to develop and spread by the late eighteenth century. It is in the context of Romantic nationalism that we may understand why particular languages and traits are ascribed to Ethiopians and Indians. The Orientalists are thus writing on the cusp of a declining Enlightenment universalism and an emerging Romantic nationalism, but are not wholly subsumed in either phenomenon. In this context, the Orientalists breathe new life into the old confusion about Ethiopia and India.

${ }^{69}$ Arno Borst, Der Turmbau von Babel. Geschichte der Meinungen über Ursprung und Vielfalt der Sprachen und Völker. 4 vols. in 6 (Stuttgart: Anton Hiersemann, 1957-1963); Daniel Droixhe, La linguistique et l'appel de l'histoire (1600-1800): Rationalisme et révolutions positivistes (Geneva: Libraire Droz, 1978) ; Hans Aarsleff, The Study of Language in England, 1780-1860. Rev. edn (Minneapolis: University of Minnesota Press, 1983). 


\section{Bibliography}

Aarsleff, Hans. The Study of Language in England, 1780-1860. Rev. edn. Minneapolis: University of Minnesota Press, 1983.

Arora, U. P. "India vis-à-vis Egypt-Ethiopia in Classical Accounts." Graeco-Arabica 1 (1982): 131-140.

Auf der Maur, Lorenz. Ethiopia and Abyssinia in English Writing up to 1790. In Proceedings of the XVth International Conference of Ethiopian Studies, Hamburg July 20-25, 2003, ed. by Siegbert Uhlig, 523-31. Wiesbaden: Harrasowitz, 2006.

Bayly, Christopher. Orientalists, Informants, and Critics in Benares. In Perspectives of Mutual Encounters in South Asian History: 1760-1860, ed. by Jamal Malik, 97-127. Leiden: Brill, 2000.

Borst, Arno. Der Turmbau von Babel. Geschichte der Meinungen über Ursprung und Vielfalt der Sprachen und Völker. 4 vols, in 6. Stuttgart: Anton Hiersemann, 1957-1963.

Briant, Pierre. Alexandre des Lumières: fragments d'histoire européenne. Paris: Gallimard, 2012.

Monboddo, Lord. [Burnett, James]. Antient Metaphysics: or, The Science of Universals. 6 vols. Edinburgh: T. Caddell, etc., 1779-1799.

Burton-Page, J. "Habshī." In Encyclopaedia of Islam, 2nd edn., ed. by P. Bearman, Th. Bianquis, C. E. Bosworth, E. van Donzel, W. P. Heinrichs, vol. 3, 14-16. Leiden: Brill, 19542002.

Campbell, Mary Baine. Asia, Africa, Abyssinia: Writing the Land of Prester John. In Julia Kuehn and Paul Smethurst, eds., Travel Writing, Form, and Empire: The Poetics and Politics of Mobility, 21-37. New York: Routledge, 2009.

Catlin-Jairazbhoy, Amy, and Edward A. Alpers. (eds). Sidis and Scholars: Essays on African Indians. Trenton, New Jersey: Red Sea Press, 2004.

Diouf, Sylviane A., and Kenneth X. Robbins. Africans in India: From Slaves to Generals and Rulers. NYPL Point, volume 2, edition 2, 2013. Available online at: http://www.nypl. org/point

Droixhe, Daniel. La linguistique et l'appel de l'histoire (1600-1800): Rationalisme et révolutions positivistes. Geneva: Libraire Droz, 1978.

Eaton, Richard M. A Social History of the Deccan, 1300-1761: Eight Indian Lives. Cambridge: Cambridge University Press, 2005.

Eaton, Richard M. The Rise and Fall of Military Slavery in the Deccan, 1450-1650. In Slavery and South Asian History, ed. by Indrani Chatterjee and Richard M. Eaton, 115-135. Bloomington: Indiana University Press, 2006.

Elliot, Sir H. M. The History of India, as Told by Its Own Historians. The Muhammadan Period, ed. [and continued] by John Dowson. 8 vols. London: Trübner \& Co., 1867-1877. 
Fiaccadori, Gianfranco. “'India' as name of Ethiopia.” In Encyclopaedia Aethiopica, vol. 3, ed. by Siegbert Uhlig, 145-47. Wiesbaden: Harrassowitz, 2007.

Franklin, Michael J. Orientalist Jones: Sir William Jones, poet, lawyer, and linguist, 17461794. Oxford: Oxford University Press, 2011.

Goldenberg, David M. The Curse of Ham: Race and Slavery in Early Judaism, Christianity, and Islam. Princeton: Princeton University Press, 2003.

Grose, John Henry. A Voyage to the East Indies; containing Authentic Accounts of the Mogul Government in general, the Viceroyalties of the Decan and Bengal, with their several subordinate Dependances. 2 vols. London: Printed for S. Hooper, 1772.

Hagerman, Christopher A. "In the Footsteps of the 'Macedonian Conqueror': Alexander the Great and British India." International Journal of the Classical Tradition 16 (2009): 344392.

Halhed, Nathaniel Brassey. A Grammar of the Bengal Language. Printed at Hoogly in Bengal. 1778.

Harris, Jonathan Gil. The First Firangis: Remarkable Stories of Heroes, Healers, Charlatans, Courtesans \& Other Foreigners Who Became Indian. New Delhi: Aleph, 2015.

Ives, Edward. A Voyage from England to India, in the year MDCCLIV. London: Printed for Edward and Charles Dilly, 1773.

Jones, William. The Works of William Jones, 13 vols. London: Printed for John Stockdale and John Walker, 1807.

Joseph, T. K. “Citerior India and Extra-Indian Indias-A Rejoinder." Journal of Indian History 25.2 (1947): 175-187. 201-207.

"India, a Continuation of Egypt and Ethiopia." Journal of Indian History 26.2 (1948):

Jowett, William. Christian Researches in the Mediterranean, from MDCCCXV to MDCCCXX. In furtherance of the objects of the Church Missionary Society. London: Published, for the Society, by L. B. Seeley, and J. Hatchard \& Son, 1822.

Karttunen, Klaus. India in Early Greek Literature. Studia. Orientalia, 65. Helsinki: The Finnish Oriental Society, 1989.

Leask, Nigel. Francis Wilford and the colonial construction of Hindu geography, 17991822. In Romantic geographies: Discourses of travel 1775-1844, ed. by

Amanda Gilroy, 204-222. Manchester: Manchester University Press, 2000.

Ludolphus, Job (Hiob Ludolf). A New History of Ethiopia. Translated by J. P. Gent, London, 1682. First published as Historia aethiopica (Frankfurt, 1681).

Nussbaum, Felicity A. Between 'Oriental' and 'Blacks So Called', 1688-1788. In The Postcolonial Enlightenment: Eighteenth-Century Colonialism and Postcolonial Theory, ed. by

Daniel Carey and Lynn Festa, 137-166. Oxford: Oxford University Press. 
Pankhurst, Richard. The Ethiopian Diaspora to India: The Role of Habshis and Sidis from Medieval Times to the End of the Eighteenth Century. In The African Diaspora in the Indian Ocean, ed. by Shihan de S. Jayasuriya and Richard Pankhurst, 189-222. Trenton, New Jersey: Africa World Press, 2003.

Parker, Grant. The Making of Roman India. Cambridge: Cambridge University Press, 2008.

Rocher, Rosane, and Ludo Rocher. The Making of Western Indology: Henry Thomas Colebrooke and the East India Company. London: Routledge, 2012.

Robbins, Kenneth X., and John McLeod. eds. African Elites in India: Habshi Amarat. Ahmedabad: Mapin, 2006.

Roy, Nilanjana S. "A Racist Turn in India." The New York Times (26 January 2014), p. SR10. Also at: http://nyti.ms/1eXF3eJ.

Schneider, Pierre. L'Éthiope et l'Inde: Interférences et confusions aux etrémités du monde antique (VIIIe siècle avant J.-C.-VIe siècle après J.-C.). Rome: École française de Rome, 2004.

The So-called Confusion between India and Ethiopia: The Eastern and Southern Edges of the Inhabited World from the Greco-Roman Perspective. In Brill's Companion to Ancient Geography: The Inhabited World in Greek and Roman Tradition, ed. by Serena Bianchetti, Michele Cataudella, and Hans-Joachim Gehrke, 184-202. Leiden: Brill, 2015.

Schwanbeck, E. A. Megasthenis Indica. Fragmenta collegit, commentationem et indices addidit. Bonn, 1846.

Selden, Daniel L. "How the Ethiopian Changed His Skin." Classical Antiquity 32 (2013): 322-377.

Shavit, Yaacov. History in Black: African-Americans in Search of an Ancient Past. New York: Routledge, 2013.

Stocking, George W., Jr. Victorian Anthropology. New York: The Free Press, 1987.

Trautmann, Thomas R. Aryans and British India. Berkeley: University of California Press, 1997. Reprint, Delhi: Yoda Press, 2004.

Vasunia, Phiroze. The Classics and Colonial India. Oxford: Oxford University Press, 2013.

Weemes [Weemse], John. The Pourtraiture of the Image of God in Man. London: Printed for Iohn Bellamie, 1627.

Wilford, Francis. "On Egypt, and Other Countries adjacent to the Ca'li' River, or Nile of Ethiopia. From the Ancient Books of the Hindus.” Asiatick Researches 3 (1792): 295-468.

"An Essay on the Sacred Isles in the West, with other Essays connected with that Work." Asiatick Researches 8 (1805): 245-367. 